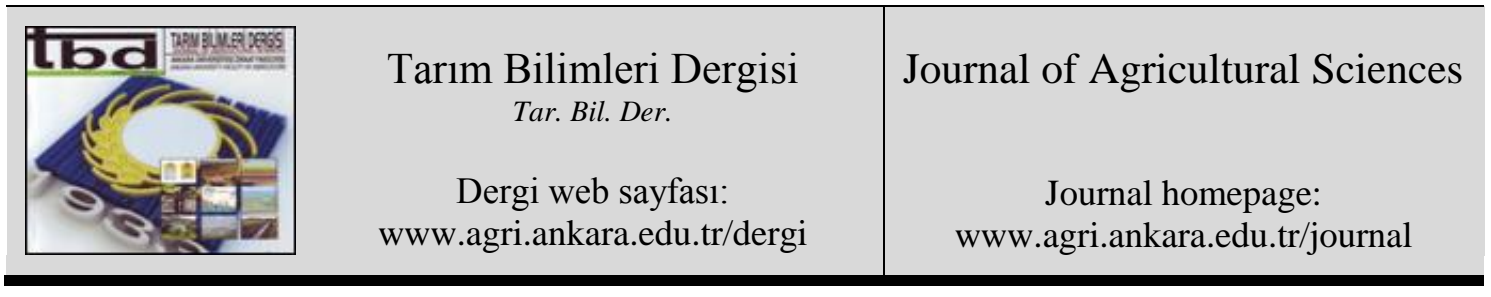

\title{
Influence of Toposequence on Physical and Mineralogical Properties of Soils Developed on Basaltic Parent Material under Sub-humid Terrestrial Ecosystem
}

\author{
Tülay TUNÇAY ${ }^{a}$, Orhan DENGiZ ${ }^{b}$, Ali İMAMOĞLU \\ ${ }^{a}$ Soil Fertilizer and Water Resources Center Research Institute, Ankara, TURKEY

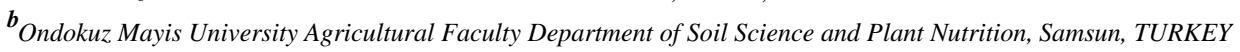

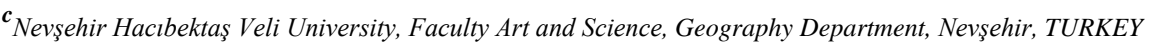

\section{ARTICLE INFO}

Research Article

Corresponding Author: Orhan DENGIZ, E-mail: odengiz@omu.edu.tr, Tel: +90 (505) 4383353

Received: 19 December 2018, Received in Revised Form: 16 January 2019, Accepted: 11 February 2019

\section{AUTHORS ORCID ID}

(Tülay TUNÇAY: 0000-0002-5719-8391), (Orhan DENGIZ: 0000-0002-0458-6016), (Ali İMAMOĞLU: 0000-0001-91971029)

\begin{abstract}
Understanding of soil forming factors is crucial to define physical, mineralogical and morphological properties of soils. In addition to that soil formations were highly associated with slope positions which have influence on pedogenetic and weathering process of the soils. Because, topography or relief affects how water and other material are added to and removed from soils. The aim of this study is to enhance our understanding of the role toposequence in controlling chemical weathering, influence on physical and mineralogical properties in soils developed on basaltic parent material under sub-humid terrestrial ecosystem in Black Sea region of Turkey using geochemical and mineralogical data obtained from X-ray diffraction and Scanning Electron
\end{abstract}

Microscope analysis. For this purpose, four representative profiles formed on different topographic positions of transect were investigated and designated according to Soil Survey Staff (2014)/IUSS Working Group WRB (2015) classification systems. The results clearly showed that topography strongly affects soil physical, mineralogical and morphological characteristics either directly or indirectly in the local region even soils formed on the same parent material with the same climatic condition. This case was also explained with chemical weathering indices (Chemical Index of Alteration and Chemical Index of Weathering) in this study.

Keywords: Toposequence; Weathering indices; Soil formation; Clay minerals

\section{Introduction}

(C) Ankara Üniversitesi Ziraat Fakültesi

Understanding of soil forming factors (e.g. parent material, climate, topography, vegetation and time) is crucial to define physical, mineralogical and morphological properties of soils. It is well known that the chemical and mineralogical composition and the physical structure of the parent material set the initial conditions of the incoming soil (Jenny 1941; Voortman 2011). Rolling topography is also another factor influence soil formation due to erosional losses, and affecting the distribution of vegetation (Florinsky \& Kuryakova 1996; Sebastiá 2004), provides climatic conditions (Grzyl et al 2014; Ridolfi et al 2008). In 
addition, topography or relief is the most important factor for soil formation affects how water and energy were added and/or lost from soil (Dengiz \& Başkan 2010). Arnold (2006) indicated that a reference relief unit was a catchment or watershed area and the analysis of lateral transfers on, in and through the soils had to be considered to understand the functioning of the landscape units. The systems could be open or close relative to the flow of water and energy. Therefore, Moore et al (1992) reported that correlations between quantified terrain attributes and measured soil attributes toposequence can be assessed.

Moreover, mineral weathering, fundamental part of pedological evaluation, also provides an essential role by transforming bedrock to weathered rock and consequently to soil that supply nutrients to ecosystems (Berner et al 1983; White \& Brantley 1995; Dixon et al 2009; Lybrand \& Rasmussen 2018; Tunçay et al 2019). In this case, during weathering, the elements are leached and accumulated in different ways due to several pedogenic processes that influence different elements and produce different results. These processes include dissolution of primary minerals, formation of secondary minerals, redox reactions, transportation of material and ion exchange (Middleburg et al 1988; Dengiz 2010). Therefore, it is important to understand how a soil is formed from bedrock and to examine how chemical or physical weathering influences the geochemical evolution of soils. As basalts locate a large part of the earth surface weathering, basalt formed by the solidification of molten materials that originated within the earth is important soil material global weathering and carbon cycling which covered a large part of the earth surface (Price et al 2005; Braun et al 2009; Heckman \& Rasmussen 2011). When basalts weather in subhumid condition, a rapid loss of cations $\left(\mathrm{Ca}^{2+}, \mathrm{Mg}^{2+}, \mathrm{Na}^{+}, \mathrm{K}^{+}\right)$and relative accumulation of $\mathrm{Si}^{4+}, \mathrm{Al}^{3+}$ and $\mathrm{Fe}^{3+}$ that yield clay minerals develops (Eggleton et al 1987; Chorover et al 2004). Furthermore, many researchers indicated that the weathering of volcanic minerals is recognized to make a significant contribution to the global silicate cycle (Louvat \& All'egre 1998; Dessert et al 2001; K1sakürek et al 2004), thus influencing carbon dioxide drawdown and climate control, since carbon dioxide is consumed particularly in $\mathrm{Ca}$ and $\mathrm{Mg}$ silicates weathering. For instance, on Deccan Traps in India, with an estimated area of $106 \mathrm{~km}^{2}$, thought to account for $5 \%$ of the global silicate weathering flux (Gaillardet et al 1999). In total, basalt rocks may account for over $30 \%$ of the global carbon dioxide drawdown in silicate weathering (Dessert et al 2003).

There are many variables including geologic, climatic and topographic state that potentially affect chemical weathering rates in earth crust (Stallard \& Edmond 1983; Grantham \& Velbel 1988). Chemical weathering indices such as Chemical Index of Alteration (used for chemical weathering in sediment area) and Chemical Index of Weathering are used to define weathering profiles (Price \& Verbal 2003). Changes in the weathering index with depth commonly are gradual or continuous, steady and systematic for homogeneous parent rocks (Sutton \& Maynard 1992) reflecting continuous leaching of elements as weathering progresses on an initially homogenous parent material. Numerous studies have been conducted on determination the extent of weathering process, soil formation (Munroe et al 2006; Anderson et al 2007; Zhang et al 2007; Brantley 2008).

The purpose of this study is to further our understanding on the role toposequence on chemical weathering, along with its influence on physical and mineralogical properties in soils developed on basaltic parent material under sub humid terrestrial ecosystem in Black Sea region of Turkey using geochemical and mineralogical data obtained from X-ray diffraction (XRD) and Scanning Electron Microscope (SEM) analysis.

\section{Material and Methods}

\subsection{Field description}

The study was conducted throughout a transverse section between Bafra Plain and Canik Mountain located around $20 \mathrm{~km}$ west of Samsun Province in the central Black Sea region of Turkey (Figure 1), where is situated at coordinates $4597065 \mathrm{~N}-253437 \mathrm{E}$ and $4595005 \mathrm{~N}-251693 \mathrm{E}$ (UTM-36N/WGS84, m).

The study area extended from $10 \mathrm{~m}$ to $300 \mathrm{~m}$ a.m.s.l (above mean sea level) and contains four distinct landscape features (foot slope, back slope, lowland plateau, and shoulder) that represent the changes in geomorphology, topographical gradient, parent material and soil characteristics. The underlying bedrock is 
primarily made up of Quaternary basaltic colluvial deposits on the foot slope and lowland plateau, and Mesozoic basalt and marl-limestone and on the back slope and highland plateau, respectively. The region is under semi-humid climate conditions in which summers are warmer than winters (mean monthly temperature in July is $22.2^{\circ} \mathrm{C}$, and in January $6.9{ }^{\circ} \mathrm{C}$ ). The mean annual temperature is $13.6{ }^{\circ} \mathrm{C}, 764.3 \mathrm{~mm}$ precipitation, and evapotranspiration is $726.7 \mathrm{~mm} \mathrm{yr}^{-1}$ (TSMS 2018). The soil temperature regime is classified as mesic, and the moisture regime is ustic (USDA Soil Survey Staff (1999). Pasture and forests are the dominant land covers. A small part of the study area is made up of a slightly-sloped (0.0 to 2.0\%) low plateau, whereas mountainous areas, and areas sloping at angles that range from moderate to severe (3\% to $20 \%$ ), are prevalent in other regions. Only a limited region of the foot slope and lowland plateau is suitable for agricultural management.

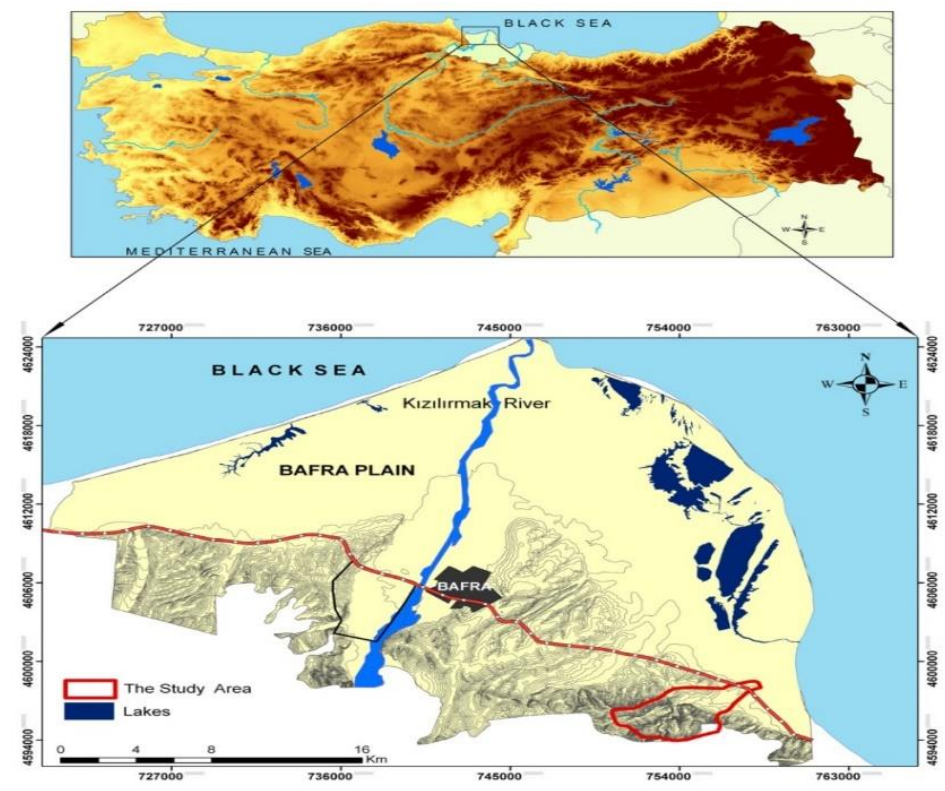

Figure 1- Location map of the study area

\subsection{Methods}

In view of the hypothesis that topography, parent material, and climate-vegetation cover may be the fundamental factors that control the mass balance in soil development, soils were investigated throughout a transverse section (diagonally in the direction from south-western to north-western) using four representative profiles (Figure 2).

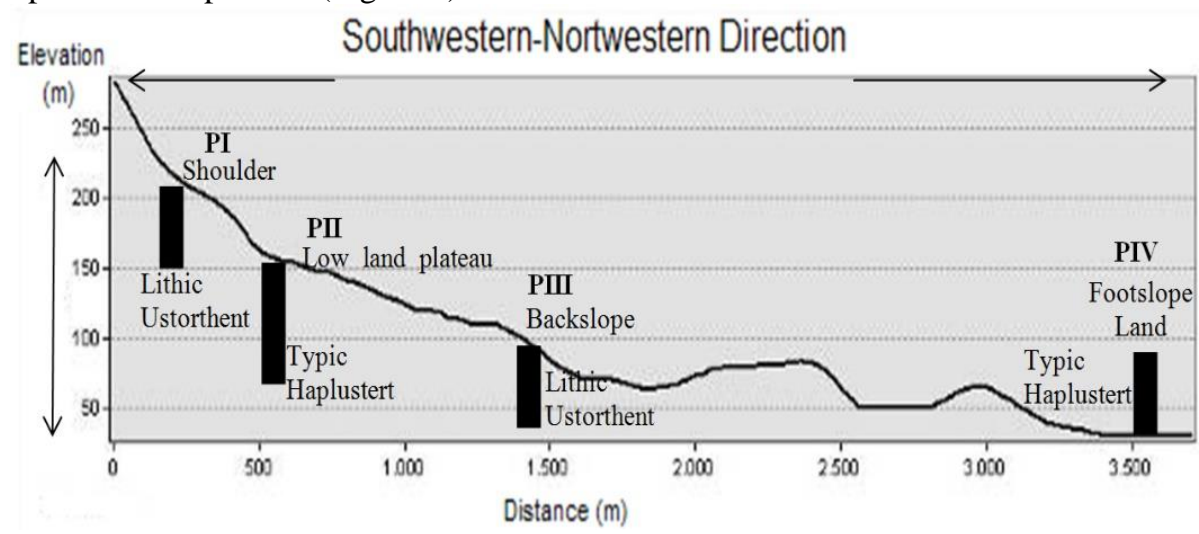

Figure 2- Transect of the four different soil profiles on basalt parent material on different topographic positions 
The morphological features of the four profiles in the field were determined, followed by sample collection using genetic horizons and classification in compliance with the Soil Survey Staff (2014). To investigate the physical, chemical, and mineralogical characteristics of the soil, twelve disturbed and twelve undisturbed soil samples were collected. Then, for laboratory analysis, the samples were first air-dried and passed through a 2-mm sieve. $\mathrm{pH}$ and electrical conductivity (EC) in 1:2.5 (w/v) in soil/water suspension by $\mathrm{pH}$-meter and EC-meter, respectively; $\mathrm{CaCO}_{3}$ content by the volumetric method (Soil Survey Staff 1992). The particle-size distribution was determined by employing the hydrometer method (Bouyoucos 1951). By following the method proposed by Blacke \& Hartge (1986), the bulk density of the samples was determined using the undisturbed soil core.

The saturated hydraulic conductivity of the samples was determined using the undisturbed soil cores by adopting the procedure proposed by Klute \& Dirksen (1986). The void ratio of the samples was calculated from the ratio of the volume of the void to that of the solids (Munsuz 1982). The porosity of the samples was calculated from the ratio of the volume of voids to the total soil volume (Munsuz 1985), and the aggregate stability was determined using the wet-sieving method proposed for undisturbed soil cores (Kemper 1965). The moisture contents of the undisturbed soil cores at pressures of $0,1,2,5,10,33,50$, 100,500 , and $1500 \mathrm{kPa}$ were determined (Klute 1986).

Following the degradation of organic matter with dilute and $\mathrm{Na}$-acetate-buffered $\mathrm{H}_{2} \mathrm{O}_{2}(\mathrm{pH} 5)$, the clay fraction $(<2 \mu \mathrm{m})$ was determined using soil dispersion with a sodium metaphosphate (calgon) and sedimentation in water. $\mathrm{Cu} \mathrm{K} \alpha$ radiation at an angle of $2 \theta$ ranging from $2^{\circ}$ to $30^{\circ}$, with steps of $0.02^{\circ} 2 \theta$ and a counting time of 2 seconds per step, specimens oriented on glass slides were analysed with X-ray diffraction (XRD). Then, $\mathrm{Mg}$ and $\mathrm{K}$ saturation, along with ethylene glycol solvation (EG) methods were applied, respectively, followed by heating at $550{ }^{\circ} \mathrm{C}$ for 2 hours. The minerals and their relative abundances were determined using the diagnostic XRD spacing of the minerals, and then evaluated using their XRD relative peak intensities obtained from the XRD graphs (Whittig \& Allardice 1986). Selected soil samples were also studied with a scanning electron microscope (SEM). In this analysis, microprobe process was not done. The samples were mounted onto aluminium stubs and coated first with carbon and then with gold. This double coating proved superior to a coating of carbon or gold alone. Each specimen was studied at magnifications ranging from 250 to 20.000 .

Various indices have been proposed to describe the weathering in soils (Harnois 1988; Nesbit \& Young 1989). The common principles upon which all indices are based on is determined by the varying ratios of some basic cations $(\mathrm{Ca}, \mathrm{Mg}, \mathrm{K}$, and $\mathrm{Na}$ ) to acidic cations of $\mathrm{Al}$ and $\mathrm{Si}$. In this study, the following indices were used to quantify the weathering rates of the profiles:

a. Chemical Index of Alteration (CIA) (Nesbitt \&Young 1982):

$\mathrm{CIA}=(100)\left[\mathrm{Al}_{2} \mathrm{O}_{3} /\left(\mathrm{Al}_{2} \mathrm{O}_{3}+\mathrm{CaO}+\mathrm{Na}_{2} \mathrm{O}+\mathrm{K}_{2} \mathrm{O}\right)\right]$

b. Chemical Index of Weathering (CIW) (Harnois 1988):

$\mathrm{CIW}=(100)\left[\mathrm{Al}_{2} \mathrm{O}_{3} /\left(\mathrm{Al}_{2} \mathrm{O}_{3}+\mathrm{CaO}+\mathrm{Na}_{2} \mathrm{O}\right)\right]$

\section{Results and Discussion}

\subsection{The clay mineralogy of the soils}

The type and amount of clay minerals have an important and active role both in the physical and chemical processes and even in the biological processes in the soils. Therefore, determining the type and amount of clay minerals is of importance to illustrate soil genesis. Clay types differ from each other in their shrinkage or expansion due to their crystal structure, the different chemical compounds they contain and the alterations caused by temperature fluctuations.

Figure 3 shows genetic horizons of the studied soil profiles, the XRD diagrams of the parent materials, 
and the SEM images (Figure 4) of the primary minerals and clay minerals. In the XRD, since $2 \theta$ values beyond 24.5 are within the range of alkali feldspar rather than clay minerals such as smectite or illite. Quartz mineral, which is among the primary minerals, is found in all the profile samples of both lines; however, the amount of quartz increased from the surface horizons to the parent material.

Moreover, Table 1 shows the prevalent clay minerals and primary minerals, and their proportion to each other, both in the genetic horizons and in the parent material. As seen in Table 1, the prevalent clay minerals suite were smectite, illite, kaolinite and vermiculite, while quartz, zeolite, with rather low Ca-feldspar and K-feldspar were the primary minerals. These findings are in agreement with the SEM images (Figure 4). However, all clay minerals were not present in all profiles, and their relative proportions in each profile and horizon differed, especially in terms of the geochemical alterations during the pedological processes.
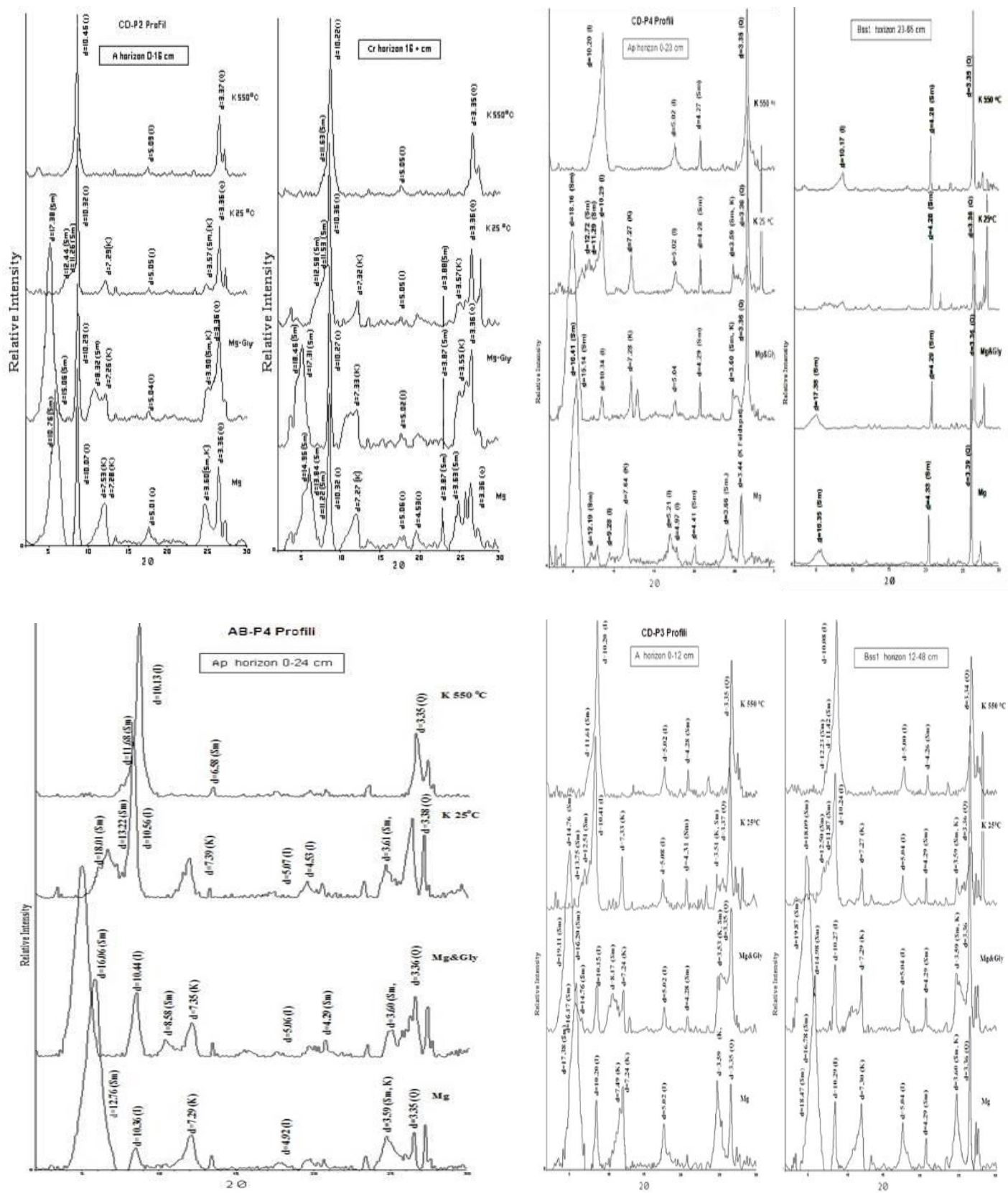

Figure 3- X-ray diffractograms of surface and subsurface horizons for each profile 
Table 1- The relative ratios of the clay fractions and clay minerals both in the horizons of the profiles

\begin{tabular}{|c|c|c|c|c|c|c|c|c|c|}
\hline \multirow[b]{2}{*}{ Horizon } & \multirow{2}{*}{$\begin{array}{c}\text { Depth } \\
(\mathrm{cm})\end{array}$} & \multicolumn{4}{|c|}{ Clay minerals } & \multicolumn{2}{|c|}{ Primary minerals } & \multirow[b]{2}{*}{$\begin{array}{c}\text { Ca } \\
\text { Feldspar }\end{array}$} & \multirow[b]{2}{*}{$\begin{array}{c} \\
\text { Feldspar }\end{array}$} \\
\hline & & Vermiculite & Illite & Kaolinite & Smectite & Quartz & Zeolite & & \\
\hline \multicolumn{10}{|c|}{ PI/Shoulder } \\
\hline $\mathrm{A}$ & $0-16$ & - & ++++ & +++ & ++ & +++ & - & - & - \\
\hline $\mathrm{Cr}$ & $16+$ & - & +++ & ++ & +++ & +++ & - & - & - \\
\hline \multicolumn{10}{|c|}{ PII/Low land plateau } \\
\hline $\mathrm{A}$ & $0-12$ & - & +++ & ++ & ++++ & + & - & - & - \\
\hline Bss1 & $12-48$ & - & +++ & +++ & ++++ & ++ & - & - & - \\
\hline Bss2 & $48-89$ & - & +++ & +++ & ++++ & ++ & - & - & - \\
\hline $\mathrm{C}$ & $89+$ & - & +++ & ++ & ++++ & ++ & - & - & - \\
\hline \multicolumn{10}{|c|}{ PIII/Backslope } \\
\hline Ap & $0-24$ & - & ++ & +++ & +++ & +++ & - & - & - \\
\hline $\mathrm{Cr}$ & $24+$ & - & - & - & - & - & - & - & - \\
\hline \multicolumn{10}{|c|}{ PIV/Footslope } \\
\hline Ap & $0-23$ & - & +++ & ++ & ++++ & + & - & - & + \\
\hline Bss1 & $23-65$ & - & ++ & - & +++ & ++ & - & - & - \\
\hline Bss 2 & $65-106$ & - & ++ & + & +++ & + & - & - & - \\
\hline $\mathrm{C}$ & $106+$ & ++ & +++ & ++ & ++++ & ++ & - & - & - \\
\hline
\end{tabular}
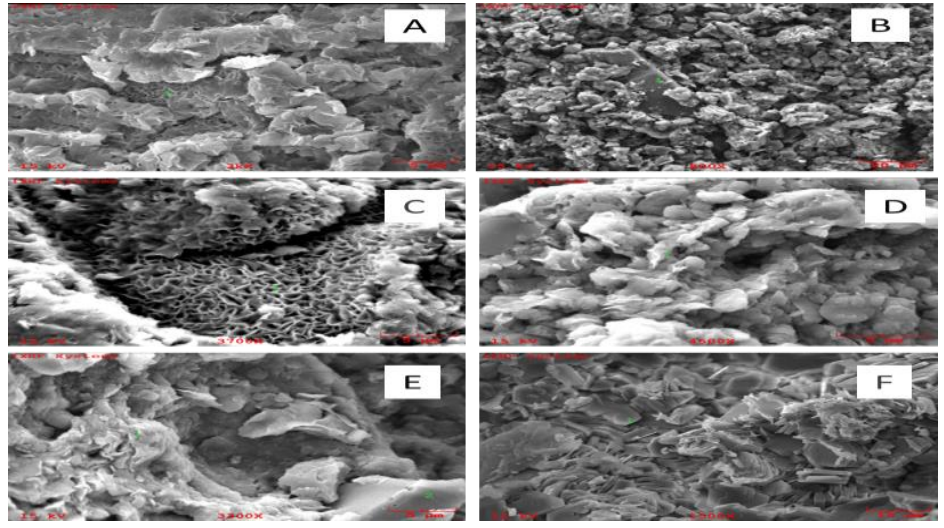

Figure 4- SEM images of clay minerals and primary mineral of soil profiles samples (A: 1: Smectite; B: 1: Quartz; C: 1: Smectite; D: 1: Illite; E: 1: Illite, 2: Feldspar and F: Kaolinite)

The profiles on the south western-north western direction reveal that, especially the soils formed on foot slope and bottom lands (Profiles PII and PIV), smectite was dominant, followed by illite, kaolinite and then vermiculite. Moreover, all profiles on this section contained the quartz at amounts ranging from low to moderate, and the tendency of its ratio to increase in the profiles from the surface to the parent material was noteworthy. In addition, albeit at a low amount, K-feldspar was observed in the surface layers of the soils in the bottom land. In their study on the effects of aspect on the weathering rates and clay mineralogy of the soils formed on andesite/trachyandesite parent materials under semi-arid conditions, Şenol et al (2014) attributed the higher amounts of K-feldspar and quartz on the northern slope soils, compared to those in the southern slope profiles, to the greater weathering over short distances due to aspect. The researchers also reported that smectite-illite-interlayered clay minerals were present in the southern slope and, in order of their abundance, illite, kaolinite and smectite were present in the northern section of the slope.

The investigation of the mineral contents of the PIII and PI profiles, classified as Lithic Ustorthent in the slope lands revealed that, among the clay minerals and primary minerals, the soils of the bottom-slope lands (PIII) contained moderate abundances of kaolinite, smectite and quartz minerals, respectively, and a low illite, whereas the upper-slope land soils, Lithic Ustorthent, mainly contained illite, followed by kaolinite and a low amount of smectite clays. Except for the surface soil of the bottom lands that contain low amounts of K-feldspar, the primary minerals that include zeolite and $\mathrm{Ca}$ - and $\mathrm{K}$-feldspars were not 
found in the soils on the section from the bottom lands. In another study focusing on the genesis and clay mineralogy of the soils formed on different vectors, physiographic units, and geological units, Dengiz et al (2006) investigated five different soil profiles that were formed on the low and high terraces in Gölbaş1 province of Ankara, on the DII, DIII and DIV plateau plains, and on different geological formations. The researchers found that the dominant clay minerals in the PI and PIII profiles, which were opened on the DII plateau plain and low terrace and classified as Entisols (Lithic Xerorthent) - contained low amounts of illite in addition to the prevalent quartz, calcite, and chlorite minerals. The PII and PV profiles that were on the DIII and DIV plateau plains, and classified as Inceptisols, had important differences in their formations and clay minerals because of their different vectors. The PIII profile that was on the high terrace plains and classified as Mollisols had a more advanced soil formation than that of the other profiles and contained illite, smectite and palygorskite clay minerals.

Illite is the dominant clay mineral in Profile I, whereas in Profile II and IV smectite was main clay mineral. XRD findings indicated distribution of clay mineral type in surface horizons vary, as follows: PI: illite > kaolinite > smectite; PII: smectite > illite > kaolinite; PIII: kaolinite > smectite > illite and PIV: smectite $>$ illite $>$ kaolinite (Table 1 and Figure 4).

\subsection{Weathering indices}

Table 2 shows weathering rates derived from the geochemical properties of the profiles in the southwestnortheast direction. The CIA value is based on chemical weathering and the removal of basic cations of $\mathrm{Ca}$, $\mathrm{Na}$, and $\mathrm{K}$ from minerals, and it represents the ratios of primary and secondary minerals in soils. CIA was calculated using the formula proposed by Nesbitt \&Young (1982). It represents the degree of hydrolytic weathering and alteration of feldspars to clays, and helps to determine the relative clay amount. The CIA value of soils or sediments that contain high amounts of intensely weathered residual clays, such as kaolinite or gibbsite, is 100, while the CIA value of unweathered, upper-crustal rock is 50 (Fedo et al 1995). The average CIA value of rocks such as shale ranges from 70 to 75 . CIA values are divided into five groups: very slightly weathered (50 to 60), slightly weathered (60 to 70), moderately weathered (70 to 80), highly weathered (80 to 90$)$ and extremely weathered (90 to 100$)$.

Table 2- The weathering indices for the profiles classified according to Soil Survey Staff/IUSS Working Group WRB on the section

\begin{tabular}{|c|c|c|c|}
\hline Horizon & Depth $(\mathrm{cm})$ & $C I A$ & $C I W$ \\
\hline \multicolumn{4}{|c|}{ PI-Shoulder (Lithic Ustorthent/Eutric Regosol) } \\
\hline $\mathrm{A}$ & $0-16$ & 55.7 & 62.0 \\
\hline $\mathrm{Cr}$ & $16+$ & 53.6 & 59.2 \\
\hline \multicolumn{4}{|c|}{ PII- Low land plateau (Typic Haplustert/Haplic Vertisol) } \\
\hline A & $0-12$ & 65.4 & 74.2 \\
\hline Bss1 & $12-48$ & 60.4 & 65.8 \\
\hline Bss2 & $48-89$ & 60.9 & 79.7 \\
\hline $\mathrm{Cr}$ & $89+$ & 50.8 & 75.1 \\
\hline \multicolumn{4}{|c|}{ PIII- Backslope (Lithic Ustorthent/Eutric Regosol) } \\
\hline Ap & $0-24$ & 58.5 & 63.9 \\
\hline $\mathrm{Cr}$ & $24+$ & 59.8 & 62.6 \\
\hline \multicolumn{4}{|c|}{ PIV- Footslope (Typic Haplustert/Haplic Vertisol) } \\
\hline Ap & $0-23$ & 61.9 & 67.7 \\
\hline Bss1 & $23-65$ & 73.8 & 80.4 \\
\hline Bss2 & $65-106$ & 42.3 & 44.5 \\
\hline $\mathrm{C}$ & $106+$ & 41.3 & 43.4 \\
\hline
\end{tabular}

There were important differences among the CIA values in the profiles on transect due to the different topographic positions. Moreover, there were significant differences among the horizons of the PIV (Typic Haplustert) where the lowest and highest CIA values were determined. Although the CIA values of the profiles on the high-slope lands were in the very slightly-weathered class, the CIA values of other profiles were either in the slightly weathered or moderately weathered class. The CIA rates of the surface horizons 
of all profiles were higher than that of the lower horizons, especially if the parent material was considered. As a result of the obstruction of the soil formation because of the continuous transport of the slope soils and upper soil to the bottom lands, the CIA values of the PIII and PI, Lithic Ustorthent in the study area, which indicate the weathering rate of the profiles, were lower than that of the other soils, which explains the weak weathering in the profiles. On the other hand, the most intense weathering occurred in PIV profile, which is located in the bottom lands, and in which the CIA values differ more dramatically depending on the parent material.

The CIW value of unweathered rock is 50 and reaches 100 in intensely weathered environments, and the CIW rate increases with increasing weathering. As with the case for CIA values, the inter-profile CIW values differed significantly and ranged from 43.4 to 80.4. The highest CIW values of the soils were determined in the PIV (Typic Haplustert), and the distribution pattern of the CIW in the profile was similar to that of the CIA. Again, as in the case of CIA as revealed by applying the same classification used for CIA to CIW - the CIW values of the PIII and PI coded profiles were in the same class due to the obstruction of the soil formation by erosion. This serves as additional evidence for the similarity between the weathering processes that occur in the soils despite the slight differences in morphology.

\subsection{The physical properties of the soils on the south western-north eastern section}

Soil physical properties showed variability as a result of dynamic interactions among natural environmental factors of climate, parent material, erosion and topography (Dengiz et al 2006; Dengiz \& Başkan 2010; Kibar et al 2012; Dengiz et al 2013). Table 3 shows the results of the physical soil analyses of the disturbed and undisturbed soil samples of PI, PII, PIII and PIV designated on the southwest-northeast section. Among the physical soil properties, the differences between the bulk density, void ratio, porosity, and waterresistant aggregate weight of the soil horizons were determined statistically significant $(\mathrm{P}<0.01)$.

Table 3- OM and some physico-chemical properties of the soils located in different topographical positions in the south western-north eastern direction

\begin{tabular}{|c|c|c|c|c|c|c|c|c|c|c|c|c|}
\hline Horizon & $\begin{array}{c}p H_{(H 2 O)} \\
1 / 2.5\end{array}$ & $\begin{array}{c}E C \\
\left(d S m^{-1}\right)\end{array}$ & $\begin{array}{c}\mathrm{CaCO}_{3} \\
(\%)\end{array}$ & $\begin{array}{l}O M \\
(\%)\end{array}$ & $\begin{array}{c}\text { Clay } \\
(\%)\end{array}$ & $\begin{array}{l}\text { Silty } \\
(\%)\end{array}$ & $\begin{array}{c}\text { Sand } \\
(\%)\end{array}$ & $\begin{array}{c}\text { Texture } \\
\text { class }\end{array}$ & $\begin{array}{c}B D \\
\left(g \mathrm{~cm}^{-3}\right)\end{array}$ & $V R$ & $\begin{array}{c}P \\
(\%)\end{array}$ & $\begin{array}{c}\text { WRAS } \\
(\%)\end{array}$ \\
\hline \multicolumn{13}{|c|}{ PI- Shoulder (Lithic Ustorthent/Eutric Regosol } \\
\hline $\mathrm{A}$ & 7.03 & 0.19 & 0.50 & 2.25 & 34.4 & 25.5 & $40.1 *$ & CL & $1.53 b$ & $0.7 \mathrm{~d}$ & $42.4 b c$ & $52.0 \mathrm{a}^{*}$ \\
\hline \multicolumn{13}{|c|}{ PII- Low land plateau (Typic Haplustert/Haplic Vertisol) } \\
\hline Ap & 7.05 & 0.16 & 0.79 & 1.71 & $41.5^{*}$ & 24.2 & 34.3 & $\mathrm{C}$ & $1.48 \mathrm{c}$ & $0.8 \mathrm{c}$ & $44.1 \mathrm{ab}$ & $11.5 \mathrm{~d}$ \\
\hline Bss1 & 7.72 & 0.19 & 0.29 & 1.69 & $68.5^{*}$ & 18.3 & $13.2 *$ & $\mathrm{C}$ & $1.48 \mathrm{c}$ & $0.7 \mathrm{~d}$ & $42.4 b c$ & $7.9 \mathrm{e}^{*}$ \\
\hline Bss2 & 7.79 & 0.34 & 1.37 & 0.59 & $49.8^{*}$ & 26.4 & $23.8 *$ & $\mathrm{C}$ & $1.53 \mathrm{~b}$ & $0.8 \mathrm{~b}$ & $45.2 \mathrm{ab}$ & $7.2 \mathrm{e}^{*}$ \\
\hline \multicolumn{13}{|c|}{ PIII- Backslope (Lithic Ustorthent/Eutric Regosol) } \\
\hline Ap & 7.87 & 0.55 & 0.49 & 2.35 & $32.1^{*}$ & $27.9^{*}$ & $40.0^{*}$ & $\mathrm{CL}$ & $1.41 \mathrm{e}^{*}$ & $0.9 a^{*}$ & $46.7 a^{*}$ & $49.1 b$ \\
\hline \multicolumn{13}{|c|}{ PIV- Footslope (Typic Haplustert/Haplic Vertisol) } \\
\hline Ap & 7.50 & 0.17 & 0.20 & 1.65 & 56.2 & 23.1 & 20.7 & $\mathrm{C}$ & $1.45 \mathrm{~d}$ & $0.8 b$ & $45.2 \mathrm{ab}$ & $7.2 \mathrm{e}^{*}$ \\
\hline Bss1 & 7.30 & 0.44 & 0.98 & 1.26 & 62.6 & $12.8^{*}$ & 24.6 & $\mathrm{C}$ & $1.57 \mathrm{a}^{*}$ & $0.7 \mathrm{e}^{*}$ & $40.9 c^{*}$ & $7.7 \mathrm{e}^{*}$ \\
\hline Bss2 & 8.25 & 0.17 & 1.10 & 1.09 & 68.4 & 15.8 & 15.8 & $\mathrm{C}$ & $1.45 \mathrm{~d}$ & $0.8 b$ & $45.1 \mathrm{ab}$ & $18.0 \mathrm{c}$ \\
\hline
\end{tabular}

OM, organic matter; C, Clay; CL, Clay Loamy; BD, bulk density; VR, void ratio; P, porosity; WRAS, water resistance aggregate btability; *, the values showed dark colour indicates the highest and lowest values. The difference between the averages showed the same letter is not significant according to the Duncan test at the 0.05 level

Although the texture classes of the soil horizon samples were clayey, the bulk densities of the soil horizon samples were generally high. Obtaining high bulk density values $\left(1.57 \mathrm{~g} \mathrm{~cm}^{-3}\right)$ - despite expecting low values - by considering the clay structure and moderately high clay content of the soils was regarded as a normal consequence of the compaction that naturally occurs in the soils depending on the climate conditions during sampling, and which increases for greater soil depths. Moreover, observing the highest bulk density in the bottom land and tilled land (PIV Typic Haplustert), and the location of the horizon (Bss1) with the highest bulk density just below the plough-till depth $(23$ to $65 \mathrm{~cm})$, indicate that the high values may also be due to agricultural activities. Again, the void ratio and porosity values, which are known to be significantly affected by compression in the soil, revealed that the void ratio and porosity values are 
decreased in soil horizons with increased compression and bulk density (PIV). It is known that there is a negative relationship between the bulk density in soil, and the porosity and void ratio. Indeed, the results given in Table 3 agree with this negative relationship. The highest void ratio and porosity values were observed in the horizon with the lowest bulk density (PIII/Ap), while the results obtained in the soil horizon with the highest bulk density (PIV) were the opposite. Furthermore, the fact that the soil horizon with the highest void ratio and porosity (PIII/Ap) was within dry agricultural land derived from forestlands having a high organic matter content $(2.35 \%)$ are also among the important indicators of the effects of organic matter on the results. Table 3 also reveals the positive effects of organic matter on water-resistant aggregates. Among the horizons with the highest water-resistant aggregate, the A horizon in the PI profile and the Ap horizon in the $\mathrm{P} 4$ profile had organic matter contents of $2.25 \%$ and $2.35 \%$, respectively, which were the highest organic matter values obtained in the toposequence. Again, when the results given in the Table are co-evaluated with the organic matter contents, it can be argued that the colloidal organic matter has a greater effect on the aggregate stability than the colloidal clay content. In agreement with this argument, the two soil horizons with the highest aggregate stability (PI/A and PIII/Ap) had the lowest clay content (34.4\% and $32.1 \%)$ and the highest sand content $(40.1 \%$ and $40.1 \%)$ among all the soil horizons identified in the section. This result is important evidence for the more effective role of colloidal organic matter in aggregate formation than that of the colloidal clay content.

Table 4 shows water retention of horizons (PI, PII, PIII and PIV) that were designated on the southwestnortheast section. The changes in the moisture content among the soil horizons at different matric potentials $(0,1,2,5,10,33,100,500$ and $1500 \mathrm{kPa})$ were found as statistically significant $(\mathrm{P}<0.01)$ (Table 4).

Table 4- The water retention of the soil horizons of the profiles located in different topographic positions in the south western-north eastern direction

\begin{tabular}{|c|c|c|c|c|c|c|c|c|c|}
\hline Horizon & $\begin{array}{c}0 \\
(k P a)\end{array}$ & $\begin{array}{c}1 \\
(k P a)\end{array}$ & $\begin{array}{c}2 \\
(k P a)\end{array}$ & $\begin{array}{c}5 \\
(k P a)\end{array}$ & $\begin{array}{c}10 \\
(\mathrm{kPa})\end{array}$ & $\begin{array}{c}33 \\
(k P a)\end{array}$ & $\begin{array}{c}100 \\
(\mathrm{kPa})\end{array}$ & $\begin{array}{c}500 \\
(\mathrm{kPa})\end{array}$ & $\begin{array}{l}1500 \\
(\mathrm{kPa})\end{array}$ \\
\hline \multicolumn{10}{|c|}{ PI- Shoulder (Lithic Ustorthent/Eutric Regosol } \\
\hline A & $37.8 \mathrm{~d}^{*}$ & $34.2 d^{*}$ & $33.7 \mathrm{c}^{*}$ & $32.5 d^{*}$ & $31.8 \mathrm{~d}^{*}$ & $31.0 \mathrm{~d}^{*}$ & $24.6 d^{*}$ & $21.7 f^{*}$ & $20.1 f^{*}$ \\
\hline \multicolumn{10}{|c|}{ PII- Low land plateau (Typic Haplustert/Haplic Vertisol) } \\
\hline A & $41.3 \mathrm{c}$ & $38.1 \mathrm{bc}$ & $37.61 b$ & $37.1 \mathrm{c}$ & $36.7 \mathrm{c}$ & $36.01 \mathrm{c}$ & $30.9 \mathrm{c}$ & $26.7 \mathrm{e}$ & $23.3 \mathrm{e}$ \\
\hline Bss1 & $47.2 \mathrm{a}^{*}$ & $45.4 a^{*}$ & $44.9 a^{*}$ & $44.4 a^{*}$ & $43.7 a^{*}$ & $42.81 \mathrm{a}^{*}$ & $39.2 \mathrm{a} *$ & $36.7 a^{*}$ & $34.4 a^{*}$ \\
\hline Bss2 & $45.7 \mathrm{ab} *$ & $43.2 \mathrm{a}^{*}$ & $42.4 a^{*}$ & $41.4 \mathrm{~b}$ & $40.0 \mathrm{~b}$ & $39.19 \mathrm{~b}$ & $36.9 a^{*}$ & $33.5 b$ & $30.1 \mathrm{~b}$ \\
\hline \multicolumn{10}{|c|}{ PIII- Backslope (Lithic Ustorthent/Eutric Regosol) } \\
\hline Ap & $42.6 \mathrm{c}$ & $39.7 \mathrm{~b}$ & $38.4 \mathrm{~b}$ & $36.6 \mathrm{c}$ & $35.5 \mathrm{c}$ & $34.58 \mathrm{c}$ & $31.1 \mathrm{bc}$ & $30.2 \mathrm{c}$ & $29.0 \mathrm{bc}$ \\
\hline \multicolumn{10}{|c|}{ PIV-Footslope (Typic Haplustert/Haplic Vertisol) } \\
\hline Ap & $41.2 \mathrm{c}$ & $39.1 \mathrm{~b}$ & $37.9 \mathrm{~b}$ & $36.6 \mathrm{c}$ & $35.7 \mathrm{c}$ & $34.53 \mathrm{c}$ & $29.4 \mathrm{c}$ & $27.3 \mathrm{de}$ & $25.6 \mathrm{de}$ \\
\hline Bss1 & $40.9 \mathrm{c}$ & $38.2 \mathrm{bc}$ & $37.5 b$ & $36.6 \mathrm{c}$ & $35.9 \mathrm{c}$ & $35.60 \mathrm{c}$ & $33.9 b$ & $30.0 \mathrm{~cd}$ & $28.0 \mathrm{bcd}$ \\
\hline Bss2 & $43.1 b c$ & $35.5 \mathrm{~cd}$ & $32.3 \mathrm{c} *$ & $31.8 \mathrm{~d}^{*}$ & $30.7 d^{*}$ & $28.80 \mathrm{~d}^{*}$ & $28.4 \mathrm{c}$ & $28.1 \mathrm{cde}$ & $26.9 \mathrm{~cd}$ \\
\hline
\end{tabular}

*, the values showed dark colour indicates the highest and lowest values. The difference between the averages showed the same letter is not significant according to the Duncan test at the 0.05 level

When the changes in moisture at different matric potentials $(0,1,2,5,10,33,100,500$ and $1500 \mathrm{kPa})$ are evaluated together, the Bss1 horizon in the PII profile had the highest moisture content, and its moisture exchange with the other soil horizons was statistically significant $(\mathrm{P}<0.01)$. However, at certain matric potentials $(0,1,2$ and $100 \mathrm{kPa})$, the Bss1 and Bss2 horizons in the PII had the highest moisture content, and their moisture contents at these matric potentials were statistically the same for each other. Among all matric potentials, the lowest moisture content was determined in the A horizon of PI.

Although the results may lead us to regard the clay content of the soils as the soil property that primarily determines the water retention capacity of the soil horizons at different matric potentials, the co-evaluation of the moisture content results given in Table 4, with the other physical soil properties given in Table 3, reveal that the rather than clay content, the clay type in the soil horizons from the transect had a greater effect on the water retention capacity of the soil than the clay content of the soil horizon. This argument is further supported by the results that showed that the Bss2 horizon of the PIV profile had the lowest moisture content at the matric potentials of $2,5,10$ and $33 \mathrm{kPa}$, although it had the highest clay content $(68.4 \%)$ 
among all the soil horizons of the section. Moreover, the low water-retention capacity of the Bss2 horizon of the PIV can also be associated with the lowest degree of weathering observed in the horizon when compared to the other horizons in the section, which was also indicated by the CIA and CIW values (Table 2). Also, conforming to the above-mentioned evaluations for the clay type, the Ap, Bss1 and Bss 2 horizons of the PIV profile with higher clay and organic matter contents had lower water retention than the Bss2 horizon of the PII profile - which had relatively lower clay and organic matter contents at almost all of the investigated matric potentials. Furthermore, it can be argued that the PII profile, which had higher water retention at all matric potentials, was more greatly affected by soil formation processes, due to the generally higher weathering indices (CIW) of its Bss1 and Bss2 horizons, compared to those of the other soil horizons; in addition, its high water-retention capacity can be attributed to the presence in these horizons of smectite-type clays able to swell to a high degree.

\section{Conclusions}

In this study, features of pedogenic evolution were tested that influence toposequence on physical, mineralogical properties and weathering rates derived from the geochemical in soils developed on basaltic parent material under sub-humid climate condition. For that reason, four representative profiles located from the south western to the north western were investigated and classified according to Soil Survey Staff (2014)/IUSS Working Group WRB (2015) classification systems. According to these systems, PI and PIII developed on shoulder and back slope were classified as Lithic Ustorthent/Eutric Regosol while, PII and PIV formed on low land plateau and footslope positions were classified Typic Haplustert and Haplic Vertisol. In this present research, it was determined that the main limitation soil forming factor on profiles development in hillslope positions (shoulder and back slope) where covered by weak vegetation is soil erosion in the study area. Therefore, soils can be described as young soils. On the other hand, soils in lower slope position (low land plateau-foot slope) have development sub surface horizon due to high clay content (generally smectite) and no interruption events. Main subsurface diagnostic horizon of these soils is slickensides (Bss horizon). This case also explained with chemical weathering indices such as CIA, CIW and investigated matric potentials which related with clay minerals. Among all the investigated matric potentials of profiles, Lithic Ustorthent soils, PI and PIII, have the lowest moisture content. Moreover, it can be said that higher water retention at all matric potentials, was more greatly affected by soil formation processes due to the generally higher weathering indices (CIA and CIW) of the slickensides horizon compared to those of the other soil horizons.

Consequently, the results clearly showed that topographic condition strongly effects on soil physical, mineralogical and morphological characteristics either directly or indirectly in the local region even soils formed on the same parent material and under the same climatic condition. This case was also explained with chemical weathering indices in this study. Therefore, the solution to stimulate soil forming and preventing soil erosion lies in directly addressing and removing the causes, e.g., stopping deforestation and the grazing on slope land and compensating the local people who are negatively affected, making contour farming and reduced tillage practices compulsory on certain slopes and soil types, and zoning high quality agricultural land to protect it from development. In addition, more scientific researches should be developed related with this topic to create site management plans in decision making and implementation in future.

\section{Acknowledgements}

The authors gratefully acknowledge the scientific research grant (TÜBİTAK-213O073) from the Scientific and Technological Research Council of Turkey.

\section{References}

Anderson S P, von Blanckenburg F \& White A F (2007). Physical and chemical controls on the Critical Zone. Elements 3: $315-319$

Arnold R W (2006). Soils: Basic Concepts and Future Challenges, ed. Giacono Certini and Riccardo Sclenghe. Published by Cambridge University Press, pp. 1-10 
Blacke G R \& Hartge K H (1986). Bulk density. In Klute, A. (ed). Methods of soil analysis. Part 1. Physical and mineralogical methods. $2^{\text {nd }}$ ed. Agronomy 9: 363-382

Bouyoucos G J (1951). A recalibration of the hydrometer method for making mechanical analysis of soils. Agronomy Journal 43: 435-438

Brantley S L (2008). Understanding soil time. Science 321: 1454-1455

Braun J J, Descloitres M, Riotte J, Fleury S, Barbiero L, Boeglin J L, Violette A, Lacarce E, Ruiz L, Sekhar M, Kumar M S M, Subramanian S \& Dupre B (2009). Regolith mass balance inferred from combined mineralogical, geochemical and geophysical studies: Mule Hole gneissic watershed, South India. Geochimica et Cosmochimica Acta 73: 935-961

Berner R A, Lasaga A C \& Garrels R M (1983). The carbonate-silicate geochemical cycle and its effect on atmospheric carbon dioxide over the past 100 million years. American Journal of Soil Science 283: 641-683

Chorover J, Amistadi M K \& Chadwick O A (2004). Surface charge evolution of mineral-organic complexes during pedogenesis in Hawaiian basalt. Geochimica et Cosmochimica Acta 68: 4859-4876

Dengiz O (2010). Morphology, Physico-Chemical Properties and Classification of Soils on Terraces of the Tigris River in the South-East Anatolia Region of Turkey. Journal of Agricultural Sciences, 16: 205-212

Dengiz O \& Başkan O (2010). Characterization of soil profile development on different landscape in semiarid Region of Turkey a case study; Ankara-Soğulca catchment. Anadolu Tarım Bilimleri Dergisi 25: 106-112

Dengiz O, Göl C, Karaca S \& Yüksel M (2006). Effects of different landscape position and parent material on soil variability and land use in both sides of Acıçay River-Çankırı. $5^{\text {th }}$ International Soil Meeting (ISM) on Soil Sustaining Life on Earth, Managing Soil and Technology: May 22-26, 2006 Şanlıurfa, Turkey 745-752

Dengiz O, Sağlam M Özaytekin HH \& Başkan O (2013). Weathering rates and some physico-chemical characteristics of soils developed on a calcic toposequences. Carpathian Journal of Earth and Environmental Sciences 8: 13-24

Dessert C, Dupre B \& Francois L M (2001). Erosion of Deccan Traps determined by river geochemistry: impact on the global climate and the $87 \mathrm{Sr} / 86 \mathrm{Sr}$ ratio of seawater. Earth Planet Science Letter 188: 459-474

Dessert C, Dupr'e B, Gaillardet J, Franc,ois L M \& All egre C J (2003). Basalt weathering laws and the impact of basalt weathering on the global carbon cycle. Chemical Geology 202: 257-273

Dixon J L, Heimsath A M \& Amundson R (2009). The critical role of climate and saprolite weathering in landscape evolution. Earth Surface Processes Landforms 34: 1507-1521

Eggleton R A, Foudoulis C \& Varkevisser D (1987). Weathering of basalt. Changes in rock chemistry and mineralogy. Clays \& Clay Minerals 35: 161-169

Fedo C M, Nesbitt H W \& Young G M (1995). Unraveling the effects of potassium metasomatism in sedimentary rocks and paleosols with implications for paleoweathering conditions and provenance. Geology 23: 921-924

Florinsky I V \& Kuryakova G A (1996). Influence of topography on some vegetation cover properties. Catena 27: 123141

Gaillardet J, Dupre P, Louvat C J \& All egre C J (1999). Global silicate weathering and $\mathrm{CO}_{2}$ consumption rates deduced from the chemistry of the large rivers. Chemical Geology 159: 3-30

Grantham J H \& Velbel M A (1988). Influence of climate and topography on rock fragment abundance in modern fluvial sands of the southern Blue Ridge Mountains, North Carolina. Journal of Sedimentary Petrology 58: 219227

Grzyl A, Kiedrzyński M, Zielińska K M \& Rewicz A (2014). The relationship between climatic conditions and generative reproduction of a lowland population of Pulsatilla vernalis: The last breath of a relict plant or a fluctuating cycle of regeneration. Plant Ecology 215: 457-466

Harnois L (1988). The CIW Index: A new chemical index of weathering. Sedimentary Geology 55: 319-322 
Heckman K \& Rasmussen C (2011). Lithologic controls on regolith weathering and mass flux in forested ecosystems of the south western USA. Geoderma 164: 99-111

IUSS Working Group WRB (2015). World References Base for Soil Resources 2014. International soil classification system for naming soils and creating legends for soil maps Update 2015, World Soil Rep., 106. FAO, Rome, 203 $\mathrm{pp}$

Jenny H (1941). Factors of Soil Formation: A System of Quantitative Pedology. McGraw-Hill, New York

Kibar M, Deniz K \& Sarığlu F E (2012). The morphology, mineralogy, geochemistry and physical implications of foid bearing syenite and syenite-carbonate rocks contact zone soils: Kırşehir-Akpınar-Buzlukdağ, Turkey. Eurasian Journal of Soil Science 2: 69-74

Kisakürek B, Widdowson M \& James R H (2004). Behaviour of Li isotopes during continental weathering: the Bidar laterite profile, India. Chemical Geology 212: 27-44

Klute A (1986). Water retention. Laboratory methods. In Klute, A. (ed). Methods of soil analysis. Part 1. Phsical and mineralogical methods. $2^{\text {nd }}$ ed. Agronomy 9: 635-662

Klute A \& Dirksen C (1986). Hydraulic conductivity and diffusivity: Laboratory Methods. Methods of Soil AnalysisPart I. Editör: Klute, A. Madison, Wisconsin: American Society of Agronomy 687-732

Louvat P \& All'egre C J (1998). Riverine erosion rates on Sao Migual volcanic island, Azores archipelago. Chemical Geology 148: 177-200

Lybrand R A \& Rasmussen C (2018). Climate, topography, and dust influences on the mineral and geochemical evaluation of granitic soils in southern Arizona, Geoderma 314: 245-261

Middleburg J J, van der Weijden C H \& Woittiez J R W (1988). Chemical processes affecting the mobility of major, minor and trace elements during weathering of granitic rocks. Chemical Geology 68: 253-273

Moore I D, Gessler P E, Nielsen G A \& Peterson G A (1992). Soil attribute prediction using terrain analysis. American Journal of Soil Science Society 2: 443-452

Munroe J S, Farrugia G \& Ryan P C (2006). Parent material and chemical weathering in alpine soils on Mt. Mansfield, Vermont, USA. Catena 70: 39-48

Munsuz N (1982). Toprak Su ilişkileri. Ankara Üniversitesi Ziraat Faktültesi Yayınları: 798

Munsuz N (1985). Toprak Mekaniği ve Teknolojisi. Ankara Üniversitesi Ziraat Fakültesi Yayınları: 922, Ders Kitabı: 260, Ankara

Nesbitt H W \& Young G M (1982). Early proterozoic climates and plate motions inferred from major element chemistry of Lutites. Nature 299(5885): 715-717

Price J R \& Velbel M A (2003). Chemical weathering indices applied to weathering profiles developed on heterogeneous felsic metamorphic parent rocks. Chemical Geology 202: 397-416

Price J R, Velbel M A \& Patino L C (2005). Rates and timescales of clay-mineral formation by weathering in saprolitic regoliths of the southern appalachians from geochemical mass balance. GSA Bull. 117: 783-794

Ridolfi L, Laio F \& D'Odorico P (2008). Fertility island formation and evolution in dryland ecosystems. Ecology and Society 13: 439-461

Sebastiá M T (2004). Role of topography and soils in grassland structuring at the landscape and community scales. Basic and Applied Ecology 5: 331-346

Soil Survey Staff (1992). Procedures for Collecting Soil Samples and Methods of Analysis For Soil Survey. Soil Survey Investigations Report No. 42, Washington DC, USA

Soil Survey Staff (1999). Soil Taxonomy. A Basic of Soil Classification for Making and Interpreting Soil Survey. USDA Handbook No: 436, Washington D.C. USA 
Soil Survey Staff (2014). Keys to Soil Taxonomy. United States Department of Agriculture Natural Resources Conservation Service Washington D.C. USA

Stallard R F \& Edmond J M (1983). Geochemistry of the Amazon 2: the influence of geology and weathering environment on the dissolved load. Journal of Geophysical Research-Oceans 88: 9671-9688

Sutton S J \& Maynard J B (1992). Multiple alteration events in the history of a sub-Huronian regolith at Lauzon Bay, Ontario. Canadian Journal of Earth Science 29: 432-445

Şenol H, Özaytekin H H, Akgül M \& Alaboz P (2014). Yarı kurak şartlarda Trakit/Trakitandezit ana materyal üzerinde oluşan toprakların ayrışma oranları ve kil minerolojine bakının etkisi. Tarım Bilimleri Dergisi 20: 288-301

Tunçay T, Dengiz O, Bayramin İ, Kılıç Ş \& Başkan O (2019). Chemical weathering indices applied to soils developed on old lake sediments in a semi-arid region of Turkey. Eurasian Journal of Soil Science 8(1): 60-72

TSMS (2018). Turkish State Meteorological Services, https://mgm.gov.tr (last access: 20 November 2018)

Voortman R (2011). Explorations into African land resource ecology on the chemistry between soils, plants and fertilizers (PhD dissertation). Faculty of Economics and Business, Vrije Universiteit, pp. 264

White A \& Brantley S (1995). Chemical weathering rates of silicate minerals; an overview. Rev. Mineral. Geochem 31: $1-22$

Whittig L D \& Allardice W R (1986). X-ray diffraction techniques. In: Methods of Soil Analysis, Part 1. Physical and Mineralogical Methods. (A. Klute, ed., $2^{\text {nd }}$ eds.), ASA publication 9, Madison, Wisconsin, pp. 55-86

Zhang G, Pan J, Huang C \& Gong Z (2007). Geochemical features of a soil chronosequence developed on basalt in Hainan Island, China. Revista Mexicana de Ciencias Geológicas 24: 261-269 